\title{
Big John Dodo and Karajarri histories
}

\author{
Darren Jorgensen
}

\begin{abstract}
John Dodo (c. 1910-2003) is known in the Australian artworld for making enigmatic sculptures of men's heads, often wearing ceremonial headbands. This essay draws on new information about Dodo from an archival interview and from the memories of his widow Aunty Rosie Munroe, as well as his grandchildren Anna Dwyer and Mervyn Mulardy Jnr. Among the Karajarri people whose country lies along the coast and inland from the community of Bidyadanga, Dodo is remembered not so much as an artist as a diplomat. Dodo played a central role in negotiating a native title case and in laying the foundations for a cultural revival among the Karajarri today. He is also remembered as a ceremonial leader and a pikkra, a person who is a root of Karajarri law. Dodo's history as a leader suggests new interpretations of his carved heads that may well represent something of this personal and ancestral power.
\end{abstract}

This essay takes several new sources of information about the artist known as Big John Dodo Nangkiriny (c. 1910-2003) to think through the significance of a series of carved heads he made over the course of his lifetime. ${ }^{1}$ These heads, often wearing ceremonial headbands, are now in museum and private collections. They are occasionally auctioned, exhibited and reproduced in publications. The literature on these heads is, however, scant, consisting largely of some brief descriptions by the anthropologist Kim Akerman whose account is repeated in auction catalogues and art gallery websites. He writes that:

1 Geoffrey Bagshaw, a friend of Dodo's, points out that Nangkiriny was his actual name. Dodo is also spelt Dudu, but I have chosen 'Big John Dodo' because this is the name and spelling used to name his work in art collections in Australia. Please note that if speaking about Dodo with Karajarri people, it is best to refer to 'Aunty Rosie's husband' or to 'the old man who carved the heads', as it is impolite to use the name of the deceased. 
It was in the early 1960s when Big John first used his artistic skills to portray the human form. This new artistic direction was the result of a dreamvisitation experienced by a Karadjeri/Nyangumarta man. In the visitation a spirit named Walkarurra taught the man a new corroboree and also instructed that two human figures be carved. Big John Dodo was chosen to carve the two figures for the corroboree. When the figures were presented to the community it was a resounding success. Encouraged by these initial sculptures, Big John Dodo experimented further, producing heads of mud, wood and stone. He finally settled on stone as a preferred medium. ${ }^{2}$

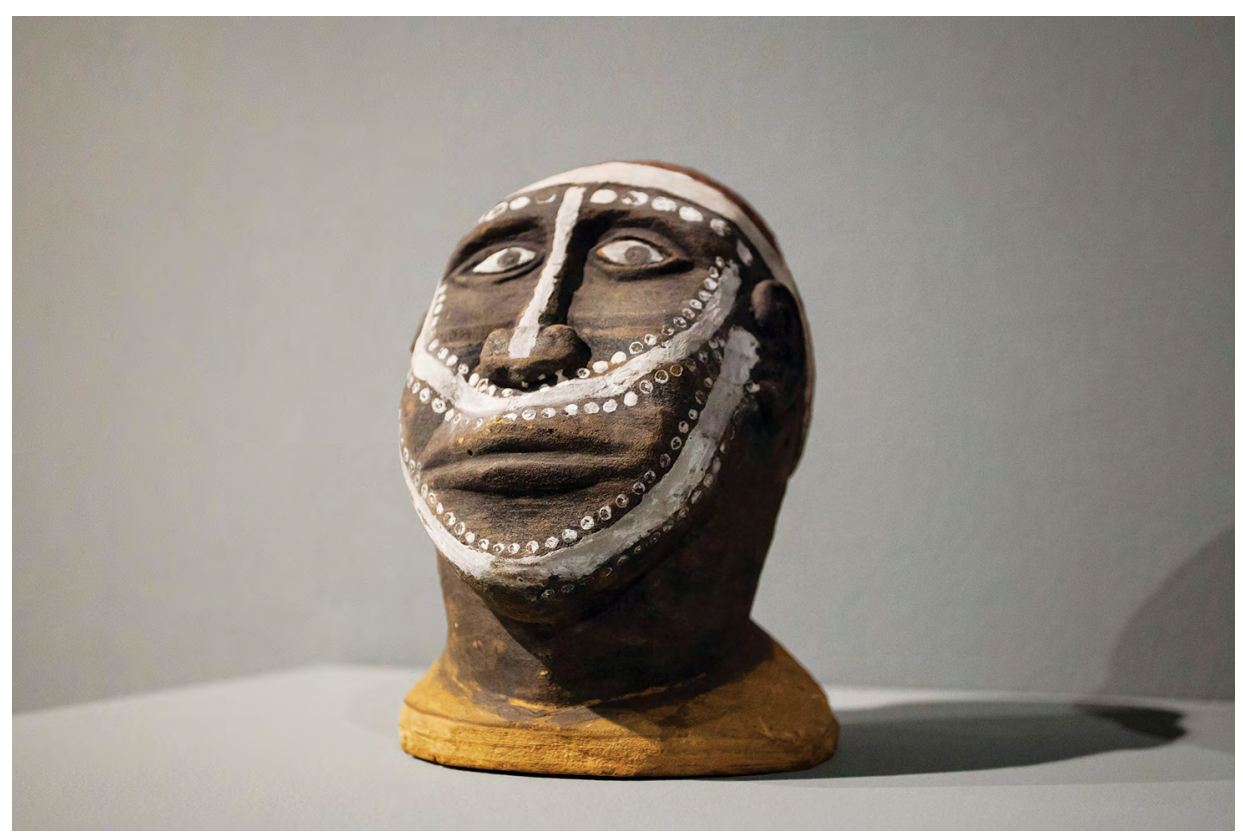

Figure 1: Big John Dodo, untitled, 1968. Carved sandstone with earth pigments, $21 \mathrm{~cm}$ high.

Source: Courtesy of H. Petri Collection, Berndt Museum, University of Western Australia, accession no. WU 5975.

The following essay complicates this origin story, putting the making of the first head back 3 decades earlier, to 1938 or 1939, when the German anthropologist Helmut Petri met Dodo on Anna Plains Station on the north-west coast of Australia. This knowledge comes from Dodo himself, who was interviewed in a video recording by the anthropologist John Stanton in 1985. This essay draws upon this recording, as well as upon recent interviews with members of the Karajarri community and Dodo's family. These interviewees include 2 of Dodo's grandchildren, Anna Dwyer

2 Ackerman, 'Stone', n.p. Note that Akerman is incorrectly spelt as Ackerman in this catalogue. This text is almost identical to the text of Anonymous, 'Big John Dodo', n.p., which is attributed to information from Dodo, Akerman and Fr Kevin McKelson. 
and Mervyn Mulardy Jnr, and his widow Aunty Rosie Munroe (see Figure 2). ${ }^{3}$ They remember Dodo less as an artist than as a ceremonial and cultural leader, who fought for the Karajarri Native Title determination, which was awarded by the Federal Court in 2002. Their memories, Stanton's interview and the exhibition history of the heads suggest several interlocking interpretations of the heads in relation to Karajarri histories that are artistic, cultural and political.

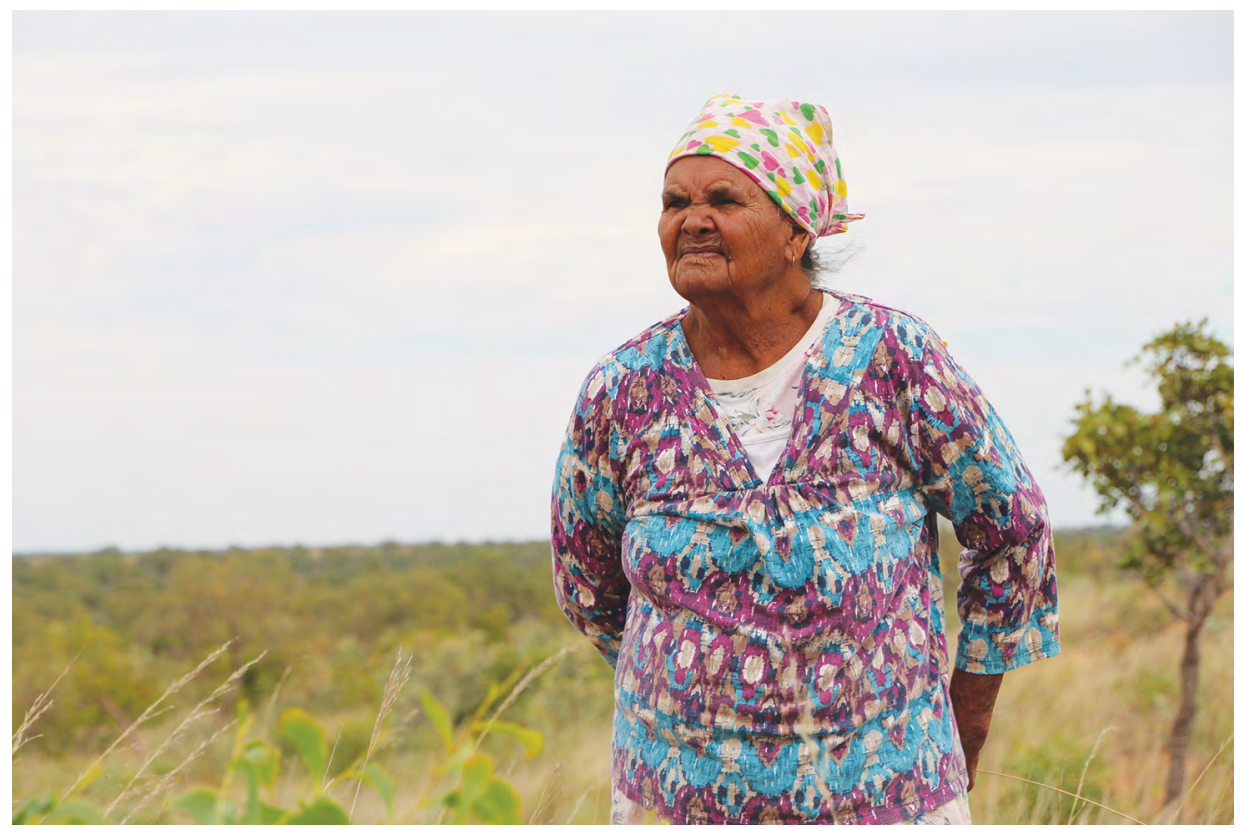

Figure 2: Aunty Rosie Munroe. Photograph by Tran Tran, AIATSIS, 2018.

Source: Reproduced with the kind permission of AIATSIS and Aunty Rosie Munroe.

\section{Dodo the Karajarri leader}

It is worth beginning by outlining the present situation of Karajarri people living in the community of Bidyadanga, because this situation constructs the way that Dodo is remembered there today. I visited Bidyadanga in May 2018, after having heard that Dodo's widow Aunty Rosie was living there. The trip was also prompted by communications with staff at the Berndt Museum, which holds the video recording of Stanton's interview with Dodo. I took a copy of this interview to Aunty Rosie. This research on Dodo fits into a larger project I am pursuing on art made on cattle and sheep stations in Australia before 1970. Such so-called 'transitional' art

3 Material from this essay is drawn from conversations with Dwyer, Munroe and Mulardy at Bidyadanga and on a bush trip during May 2018. The final publication was reviewed and approved by the Karajarri Rangers in correspondence with the author, 30 October 2018. 
is neither classical, emulating pre-colonial forms, nor contemporary, produced with entirely new materials such as paint and canvas. ${ }^{4}$ When I arrived in Bidyadanga, the Karajarri Rangers' headquarters was alive with people preparing for bush trips and looking at photographs of people taken in the 1970s, and kept since then in the Australian Institute of Aboriginal and Torres Strait Islander Studies (AIATSIS) archive: it turned out that I was not the only person bringing materials from museums to show Karajarri people. My visit and that of AIATSIS staff was part of broader revival of Karajarri cultural life.

Mervyn Mulardy Jnr is the Karajarri cultural programs coordinator, and he described to me the way that Karajarri people are focusing on performing ceremonies, and on repatriating stolen human remains, as well as visiting old rock art sites and jila (places where underground water comes to the surface, which Karajarri people traditionally imbued with spiritual significance). ${ }^{5}$ Mulardy is spearheading a proposal for the Karajarri to set up their own cultural organisation to further the aim of strengthening cultural activities. It has not always been like this, however, and both Mulardy and Dwyer testify to Dodo's role in laying the foundations for this cultural revival. While Mulardy remembers Dodo's ceremonial significance (Mulardy was initiated by him), Dwyer recalls Dodo's leadership on the native title process after it commenced in 1995.

It was of particular significance for the Karajarri to be awarded the rights to their country, since it has long been home to groups of Aboriginal people who had migrated from elsewhere. As La Grange, it was a post office and a government ration station for Aboriginal people before becoming a Christian mission in $1955 .{ }^{6}$ These migrations were often forced, as in the arrival of Mangala and Nyikina speakers who were brought on trucks from the government settlement of Udialla in 1949. ${ }^{7}$ However, people did have some freedom of movement, as illustrated by those of this group who returned to live in their desert country before returning once more to La Grange in the mid1950s. ${ }^{8}$ Many La Grange residents also chose to work periodically for neighbouring pastoral stations, returning in the summer when the work slowed down. The Udialla group remained a distinct one at La Grange, bringing with them syncretic, antiEuropean cult ceremonies that also incorporated Christian beliefs. ${ }^{9}$

The arrival of desert people with powerful, esoteric ideas is not an uncommon story in the north-west of Australia in this period. Settlements on the edges of the Great Sandy Desert such as Fitzroy Crossing hosted migrations of people away from

\footnotetext{
4 See Jorgensen, 'The Art of Station Time'.

5 See Mulardy, Shoveller and Williamson, 'Karajarri Country'. On the importance of jila to Karajarri and Dodo, see Yu and Yu, 'Living Water'.

6 Edgar, 'Indigenous Land Use Agreement', 52-53.

McKelson, 'Nadya Nadya Country', 215; Petri and Petri-Odermann, 'Stability and Change', 270.

Petri and Petri-Odermann, 'Stability and Change', 270.

Petri and Petri-Odermann, 'Stability and Change', 263.
} 
a drought, and these people brought with them their own ceremonies and laws. ${ }^{10}$ As it became more populated, La Grange became a centre for ritual activity, and not only for the Udialla migrants. The Nyangumarta moved their ceremonial base from Anna Plains Station to La Grange, following a shift in population as seasonal pastoral workers took up residence there, and away from the station. ${ }^{11}$ Before this, Anna Plains was typical of many pastoral stations at the time that hosted rich ceremonial activity between station work. ${ }^{12}$ At La Grange, the ritual worlds came into conflict, as ideas from the desert appeared to be incompatible with those of the coastal people. ${ }^{13}$ Mulardy recalls this history as he reports that the desert people went so far as to initiate Karajarri youths, to the detriment of local culture. He says that 'they didn't respect bosses for country like this old man here', referring to Dodo. ${ }^{14}$

While Mulardy recalls Dodo's push to strengthen the position of Karajarri landholders, Dwyer remembers him as a peacemaker. Dodo's leadership in the native title agreement process is remembered as a feat of negotiation in a legally and often interpersonally complex area. Geoffrey Bagshaw, an anthropologist who worked with Dodo on the native title claim, remembers his strength of character, writing that:

Even in advanced old age (I knew him during the years when he was about 85 through to 90) he was mentally alert, gentle, patient, considered, fair-minded and extremely knowledgeable. He was certainly a man of high degree, as the noted anthropologist A.P. Elkin would no doubt have called him. ${ }^{15}$

Dwyer compares Dodo to Nelson Mandela in his fight not only to empower the Karajarri but also to ensure that they were able to live alongside the other residents of Bidyadanga. In this, Dodo carried on long processes of cross-cultural negotiation that Karajarri had been involved with at La Grange.

Anthropologists Helmut Petri and Gisela Petri-Odermann visited La Grange through the 1950s and 1960s, and witnessed Karajarri man Jack Muladi struggling to run meetings between the different people living there, and to counter the dominance of desert groups. ${ }^{16}$ It was during this period of heightened ceremonial activity that Dodo's dream-visitation bestowed his carvings with ritual authority. The new ceremony that Dodo received from the spirit world brought the Karajarri and Nyangumarta together, in a precedent for the native title agreement of 2002 that would see Dodo again at the centre of negotiating between these 2 groups. As a Karajarri man who had lived most of his life on Nyangumarta country on

10 Hawke, A Town Is Born, 196.

11 McKelson, 'Nadya Nadya Country', 216.

12 Foster, 'Rations, Coexistence', 20; Shaw, Countrymen, 159.

13 Petri and Petri-Odermann, 'Stability and Change', 270-72.

14 Mulardy, in conversation with the author, 24 May 2018.

15 Geoffrey Bagshaw, private communication, 11 June 2018.

16 Petri and Petri-Odermann, 'Stability and Change', 271, 274. 
Anna Plains, Dodo was ideally placed to bring these people into close rapport. Understanding the multiple obligations and relations between Aboriginal people was even more complex during this period of rapid change, as people moved from place to place amid the changing regimes of government and pastoral power. ${ }^{17}$ Conditions of labour on pastoral stations were quickly changing too, as they were mechanised and regulated by a government newly concerned with the fate of Aboriginal people in remote Australia. ${ }^{18}$ Such changes led to religious revivals across the north-west, as ritual activity attempted to make meaning out of these transformations, and took advantage of new opportunities to travel. ${ }^{19}$

Dwyer's comparison of Dodo to Mandela is also a comparison of the history of north-west Australia to South Africa. For it was also in South Africa that non-whites worked for little pay and with little legal recourse. In the north-west of Australia, Aboriginal people worked much of their lives for cattle stations who paid little for their labour. Munroe remembers the 'hard work for nothing', work that for her included gardening, ironing and washing clothes. For Dodo this work would have consisted of branding, fencing, maintaining water supplies and droving cattle to Meekathara in a trip on horseback that could take 12 to 16 weeks. ${ }^{20}$

Conditions for Aboriginal labourers began to change in the north-west during the 1960s; as cattle and sheep began to be moved on trucks, missions like La Grange became more attractive, and stations became more reluctant to employ Aboriginal workers as they demanded and were legally awarded wages. ${ }^{21}$ When Anna Plains passed to new management, Dodo and Munroe were evicted from their home along with other Aboriginal families. Munroe remembers that they were able to take refuge on another station for around 18 months before moving finally to the La Grange mission. ${ }^{22}$ The shift was traumatic for Munroe who had been born onto Anna Plains, and who had known no other home. Dodo was also intimately tied to Anna Plains, not only through decades of labour, but also because he was initiated at Yawinya on the station. ${ }^{23}$ 'Little by little', Munroe remembers, 'people moved to Bidyadanga' (that was then called La Grange), steadily expanding its population as stations evicted Aboriginal people, and new groups moved in from the Great Sandy Desert.

17 McKelson, 'Nadya Nadya Country', 216.

18 See Bunbury, It's Not the Money.

19 Akerman, 'The Renasence of Aboriginal Law in the Kimberleys'; Petri and Petri-Odermann, 'Stability and Change'.

20 Thom, 'Kimberley: Out on the Ridges'.

21 Petri and Petri-Odermann, 'Stability and Change'; Thom, 'Kimberley: Out on the Ridges'.

22 I was not completely clear in my discussions with Dwyer on the name of this station, but it is likely to be Nita Downs as the source of Dodo's sandstone lies within Nita Downs, on the boundary with Anna Plains.

23 Geoffrey Bagshaw, personal communication, 11 June 2018. 
Publications on art from Bidyadanga invariably tell the story of the Yulparitja, who were the last of the desert groups to move there, arriving in the years between 1967 and 1974. ${ }^{24}$ They began painting the waterholes along the Canning Stock Route, and other sites on their country, more than 30 years after leaving it. ${ }^{25}$ It is a sign of how far the Karajarri have come in empowering themselves on the community since the 1960s that the Yulparitja set out to ask permission of the Karajarri to paint. Some reports argue that this painting movement was in fact inspired by the 2002 native title decision to recognise Karajarri country. ${ }^{26}$ Whatever its origins, after meeting with the Karajarri the Yulparitja decided to paint in saltwater colours, including blue and green, in homage to the Karajarri country on which they lived. Such colours now mark out Bidyadanga paintings from other Western Desert paintings, which are typically in more earthy tones. Although they paint with blues and greens, the subject of Yulparitja paintings are of sites in the Western Desert, sandhills and waterholes that are remembered by the older artists. When I asked Mulardy about this painting movement and its negotiation, he said that other people could do what they liked, but that the Karajarri had to focus on the Karajarri, that 'now Karajarri people think for themselves, build on their own country and not worry about everybody else'. For Mulardy this is 'closing the gap', appropriating the name of a government and community campaign to end the gap in health and life expectancy between Aboriginal and non-Aboriginal Australians in order to describe the way in which they have empowered themselves after a period of accommodating the newcomers. Today he emphasises that 'I believe we have closed the gap'. The tension within Karajarri history, however, lies on Mulardy's mind, and is a tension that constructs his memories of Dodo, the way in which 'he didn't speak for anybody else'. ${ }^{27}$

\section{Dodo the artist}

It is with this complex history in mind, a history that is central to the lives of Karajarri people, that we arrive at Dodo's carved heads. In his interview with Stanton, Dodo recalls the first head that he made:

I was working on the station, and so I got this station man wanted the place, so he told me to go and clean the tank out. Mud was full in the tank and I had a few blokes with me, to get the mud out of the tank and just chuck it in the barrel, we worked well together, sure we didn't get that done in the one day, there was too much mud on. Took three days to get the tank filled out, so I had a bit of a look around. At same time the mud started to get cracked

\footnotetext{
24 McKelson, 'Nadya Nadya Country', 216-17.

25 Rohr, 'Bidyadanga'.

26 See Ashley Crawford, 'Yulparija Show Their Colours', Age (Melbourne), 19 April 2004; Lydia Harvey, 'Announcing Director's Choice: Lydia Balbal', email correspondence, Harvey Art Projects, 18 February 2014.

27 Mulardy, in conversation with the author, 24 May 2018.
} 
and dry out and so I started to think about. The mud will crack, and I think about, and I start messing about. I'll try and make a man's face, do it good you know, so I get on with that job, with soft mud, working with a pocket knife, and face and nose and skin ... so I make a man's face ... and then so I think I'll take him back to the camp, I'll show all my people, and so I took him back home.

At the same time the one Dr Petri was there on the station. So he was studying with the people, talking about the study why did it happen, all about with the old people. So I accompany him and I showed that thing what I made and he says ooh geez ... He said to me where you get this from, and I said oh well I get it out of the tank, too much mud, I been working on the tank cleaning mud out, and I think about it ... So he says it's done very well, ooh that good one ... and he says oh I haven't seen one like this before, he hadn't seen one to make a face like a human, he was very pleased to see this. ${ }^{28}$

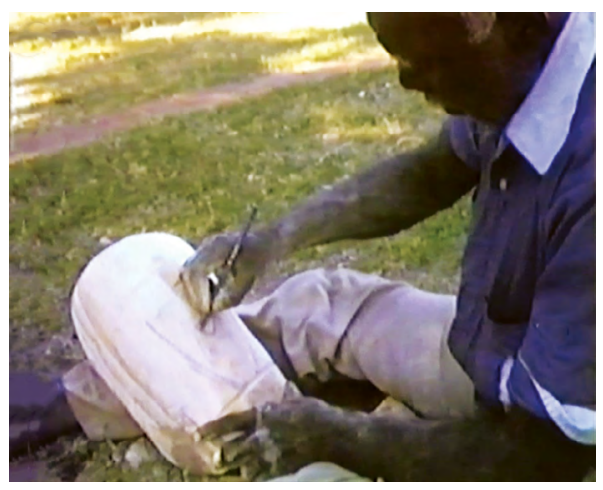

Figure 3: Dodo carving in 1985. Still picture taken from video interview with John Stanton.

Source: Reproduced with the kind permission of the Berndt Museum, University of Western Australia and Aunty Rosie Munroe.
This took place during 1938 or 1939, when Petri was on Anna Downs. This first mud head, however, fell apart, and upon Petri's return to the north-west in the late 1960s he collected a second head, this time made of limestone (Figure 1) ${ }^{29}$ It is not clear whether Dodo was living at Anna Plains, La Grange or another station at the time of Petri's second visit. Petri recalls that, "The head was made in 1969, and was the first attempt to carve a portrait out of the soft limestone (?) you find at some parts of the coast of La Grange country'. ${ }^{30}$ While this is certainly the oldest of Dodo's heads that survives, Petri may be mistaken in writing that this was the first head that Dodo made of stone. Akerman reports that Dodo carved ceremonial heads in the early 1960s, and these may have been from stone, mud or even wood. Sandstone proved a spectacular

28 Big John Dodo, interview with John Stanton, 1985, Berndt Museum, University of Western Australia.

29 Dodo, interview with John Stanton, 1985.

30 Petri to Stanton, 8 October 1985, Berndt Museum, University of Western Australia. 
medium, however, as the lines of colour in the stone accentuates the curve of the face as it recedes into the shape of the skull. The rear of these carvings often feature beautiful lines that simulate tied-back hair.

During the 1970s, the heads were sold by Mary Macha, who collected work across the Kimberley for her government-owned shop Aboriginal Traditional Arts Gallery in Perth. At this time, Dodo and Munroe were living at Bidyadanga, and it is likely Macha visited there on her collecting trips through the Kimberley, commissioning them from him. The earliest head with such a provenance was made in 1974 and bought from Macha in 1975 by anthropologist Ronald Berndt, before being put on display in the University of Western Australia anthropology museum (Figure 4). This commercial phase of head making culminates in the mid to late 1980s when the developer Alastair (Lord) McAlpine took an interest in them.

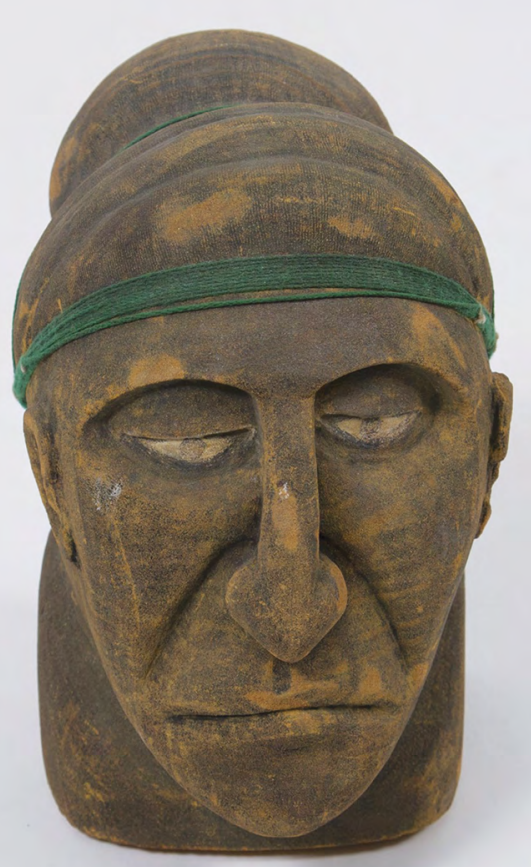

Figure 4: Big John Dodo, Human Head, 1974. Carved sandstone with green dyed wool, $21 \mathrm{~cm}$ high.

Source: Courtesy the Berndt Museum, University of Western Australia, accession no. 2040. 
Kevin McKelson, priest and linguist at Bidyadanga for 30 years, remembers that McAlpine's interest in the heads was inspired by a visit to the Bidyadanga Church in 1984, where a head is still displayed as an altarpiece today. ${ }^{31}$ In his interview with Stanton, Dodo remembers this display prompted people to want to buy heads, as people visited the church at Bidyadanga. Stanton also recalls that McAlpine saw one of Dodo's carved heads on display in the anthropology museum sometime in the 1980s, and this may well have preceded his visit to Bidyadanga. ${ }^{32}$ McAlpine was a major developer in Broome, and operated an arts and artefact outlet from Broome Zoo that he also built. Through this outlet, he commissioned 100 heads for AU \$1,000 per head. In today's terms, Stanton calculates that each head was worth AU \$3,900, an incredible amount of money in a period of high unemployment for Australia, and for remote Aboriginal people who were among the most impoverished in the country. ${ }^{33}$ The offer stimulated other people in Bidyadanga to take up carving, some from other language groups beside Karajarri. The majority of heads that turn up for sale at auction or second-hand in Australia today are not by Dodo, but these other carvers. During the period these heads were made, in the 1980s, Munroe remembers Dodo carving day after day under a tree in Bidyadanga (see Figure 3). This is likely to be the same tree under which Stanton interviewed him amid this frenzy of carving activity, in 1985, and amid the noise of community life.

\section{The history and meaning of Dodo's Karajarri heads}

For what reason did Dodo carve these heads? While money was certainly a motivation for later works, and the prompting of Petri a reason for the revival of Dodo's carving in the 1960s, this does not explain everything. Munroe, who was busy raising a family at the time Dodo was busiest carving, thinks he did it 'for fun'. Dodo's own account of carving from mud supports her interpretation, while a second reason may lie in his working on stations. Munroe remembers him carving whip handles in this period, handles that may have been decorated, and this history of woodcarving may have influenced his heads. Few surviving examples of these handles, carved across the country by Aboriginal and non-Aboriginal stockmen, have survived. Those examples that are in museum and private collections tend to feature figurative designs, including heads, snakes and representations of the overlaid weaving of leather that tied the whip to the handle. ${ }^{34}$ When I asked Munroe

31 McKelson, 'DODO', 575. Mary Macha also told me this story in a private conversation, 2 November 2016.

32 Private correspondence with John Stanton, 18 July 2017.

33 Private correspondence with John Stanton, 18 July 2017.

34 See Grosskopf, Australian Stockwhips. 
about Dodo's whip handles, she spoke of this weaving pattern, and it may be that Dodo carved this design into his handles, although I did not get a chance to show her a similar design.

Akerman reports that Dodo had experience carving human figures for ceremony, and it is likely he also carved boomerangs, shields and other items of classical cultural practice. ${ }^{35}$ Petri photographed boomerangs and shields that were made at La Grange in 1960, and many attributed to La Grange turn up in specialist auctions today, telling of a longer history of a carving industry at the mission and through the region. ${ }^{36}$ In any case, the hard work that characterised Dodo's life as a stockman, and as a carver, may constitute a second reason for Dodo's interest in making heads, as he turned his hand to this new kind of carving.

Such reasons do not, however, explain either the choice of subject, the head, or the ongoing inspiration to ornament these heads with ceremonial painting. Here it is possible to draw upon the concept of under-interpretation to think through the many aspects of the heads, and the ways in which the heads represent several aspects of Dodo's life. In his book Aboriginal Artists of the Nineteenth Century, Andrew Sayers uses this concept to describe the way in which under-interpretation can be used 'in acknowledgement of the impossibility ... of selecting a meaning from a range of possible and often divergent meanings that might be attached to any of them' ${ }^{37}$ The approach runs counter to much of the theoretically sophisticated new art history that has dominated scholarship on art since the 1970s, which instead over-interprets works to determine their ideology, their function and place within Western systems of power. ${ }^{38}$

When I asked Munroe about the meaning of the heads, and whether they derived from ceremony or tradition, she laughed and said that the decorated faces were something of a trick to bring the faces to life. However, she also pointed out that the limestone the heads were carved from was from a site of some significance to Karajarri people. It is possible to speculate on the place of the heads within a particular Karajarri Dreaming; however, we should recall Munroe's memory of Dodo carving for fun and money, rather than with the Dreaming foremost in mind. One meaning does not exclude the other, however, as they can be read as both divergent and simultaneous. McKelson quotes Dodo telling the Dreaming story of Mount Phyre (also spelled Payarr):

A family from ancestral times ... were hunting near Eighty Mile Beach, or Mt Payarr. The young son killed a female goanna heavy with eggs and ate them—an act which was taboo. This angered Pulanj, the rainbow serpent,

35 Ackerman, 'Stone', n.p.; Anonymous, 'Big John Dodo'.

36 State Library of Western Australia, BA368/9: 24.

37 Sayers quoted in Allbrook, 'George Coolbul', 54.

38 Harris, The New Art History. 
who sought revenge first by unleashing violent storms and then by setting out to devour the boy. However the boy's father was a medicine man and had the power to seal the cave in which his family took refuge to withstand repeated attacks by the serpent. Enraged and with gaping jaws it attacked the mountain itself, biting off large chunks of rock. This continued throughout the night whilst the petrified family huddled inside. Finally, at dawn, the Serpent withdrew and the rain stopped..$^{39}$

Akerman reads Dodo's sculpture as expressing something of this medicine man. In 2010, he writes that, 'Dodo's sculpture, carved from the very stone crushed by Pulany, represents the jalnganguru whose powerful spells saved his family'. ${ }^{40}$ Dodo alludes to this expanded meaning for his sculptures in a remark in the 1985 interview. Amidst talking about making heads decades ago, he says that, 'I think about him, about carving on big mountain, on big stone, that is what I think about, it might have been some beginning from the old stories ... that is what I think about when carving, you know. ${ }^{41}$

How to interpret Dodo's enigmatic statement? Here we might turn to Minoru Hokari, who, after spending time with Gurindji people in the north of Australia, writes of the way in which Aboriginal history is constituted by something he calls 'the voice of the earth'. ${ }^{42}$ Hokari argues that this is not a metaphor for the Gurindji people he has spent time with, but an active agent in their consciousness, and their consciousness of Gurindji history. Here 'him, about carving on big mountain' and 'might have been some beginning from the old stories' sounds like a description of the Dreaming itself, that long ago creation of the world that remains powerfully at work in remote Australia.

Mulardy, who went through ceremony with Dodo, testified to Dodo's intimacy with the country when he tells of bringing Dodo's body back down the road from the town of Broome for Dodo's funeral. It was a still day, rare in the expanses of the north-west, but when he crossed back into Karajarri country the wind suddenly blew up, as the country saw that Dodo was coming home. Dodo was for Mulardy a pirrka, literally translated as 'root' of Karajarri law, one who is deep in knowledge and customs of the country. ${ }^{43}$ The process of carving may have been a way of being a pirrka. As Dodo created these heads from the mountain, so the mountain was created by the Pulany, in a conception of art that encompasses the art by which the world is made. The process of creating the world, carving the heads, and ceremony are all interrelated. As the heads bring Dodo's power as a diplomat and pirrka to mind, the Karajarri configure a history in which he was central to their cultural and political revival.

39 McKelson, 'DODO', 575-76.

40 Akerman, 'Big John Dodo'.

41 Dodo, interview with John Stanton, 1985.

42 Hokari, Gurindji Journey, chapter 1.

43 Private correspondence with Geoffrey Bagshaw, 11 June 2018. 
This interpretation of Dodo's heads as being at the centre of Karajarri ceremonial and political history constitutes what Howard Morphy has called an Aboriginal art history. This is a history in which Aboriginal discourses and concepts contribute to an understanding of Aboriginal artworks, and to the comprehension of more universal questions around the role of art in the societies to which they belong. ${ }^{44}$ Aboriginal art history is by its nature a cross-cultural art history because it is constituted by the intersection of Western art history and Aboriginal art. ${ }^{45}$ Morphy's description of the bir'yun, the shimmering effect of ancestral power in the crosshatching of Arnhem Land painting, is an influential example of this kind of crosscultural art history. ${ }^{46}$ Bir'yun has been translated as both brilliance and shimmer, and used extensively by non-Indigenous writers to theorise Kunwinjku and Yolngu painting. The difference between Dodo's works and that of the intergenerational art movements of Arnhem Land, however, lies in the way that his heads were largely anomalous and idiosyncratic. While they briefly inspired collectors and imitators, they did not bring about an art movement of any scale, and were not subject to an Aboriginal discourse that would constitute their meaning.

Curatorially, Aboriginal artworks have for the most part been exhibited in special sections of Australian public galleries, and in a network of dedicated private galleries that established itself in the 1980s. Dodo's carvings are no exception, and were largely exhibited alongside other Aboriginal art through the 1980s and 1990s, at the Berndt Museum, the National Gallery of Australia and in the 'Paper, Stone, Tin' exhibition at the Tandanya National Aboriginal Cultural Institute in Adelaide in $1990 .{ }^{47}$ In recent years, however, art history and exhibition practices around Aboriginal art have become more interested in the relationships of its artists to non-Aboriginal art and artists. Curatorial strategies have become more interested in creating new relationships, rather than affirming the Aboriginality of Aboriginal art.

The National Portrait Gallery may have been the first to use Dodo's heads outside dedicated Aboriginal art galleries. They included Dodo in 2 exhibitions of portraiture, The Possibilities of Portraiture in 1999 and Presence and Absence: Portrait Sculpture in Australia in 2003. In 2016 Dodo's 1969 head, the one collected by Petri, was included in an exhibition that focused on Dutch colonial history, Invisible Genres at the John Curtin Gallery in Perth. Sitting alongside work by Australian, Dutch, Indonesian and South African artists, Dodo's carved head was used to illustrate the complexity of responses to the disruptions of colonial society. ${ }^{48}$ Although featuring only Aboriginal work, the 'Paper, Stone, Tin' exhibition of 1990 made a similar

\footnotetext{
44 Morphy, 'Art Theory'.

45 Morphy, 'Art Theory'; Morphy, 'Moving the Body Painting into the Art Gallery'.

46 Morphy, Ancestral Connections, 194.

47 Ackerman, 'Stone', n.p.

48 See Mateer, 'Invisible Genres'.
} 
point. It featured Dodo alongside old ceremonial masks, spirit and animal drawings, in the process illustrating several very different responses to fast-changing regimes of power in north-west Australia.

There are, then, several interpretations of Dodo's heads, each of which complement each other, as the heads symbolise personal, political and ceremonial histories of north-west Australia. While the heads remind Dwyer of Dodo's diplomacy, Mulardy recalls his pirrka qualities, and Munroe proposes they were carved for pleasure. Akerman and McKelson correlate the heads with the Dreaming story of Mount Phyre, while curators have used Dodo's work to emphasise the colonial history of north-west Australia. Such overlapping interpretations speak of Dodo's power as a pirrka, artist and diplomat. These interpretations are, however, also produced at different times, and follow the concerns of different generations of Karajarri people, anthropologists and curators. They do not anticipate what the heads might mean for generations to come, instead being indicative of the concerns of those who are invested in Dodo's legacies, whether this be as an artist, ceremonial leader or native title campaigner. That he occupies these multiple roles is symptomatic of the way such realms are not distinct from each other within remote Aboriginal communities, but are intertwined. The authentication of the heads as ceremonially significant in the early 1960s with the dream-visitation of Walkarurra, anticipates the place of Dodo in Karajarri history, making him central to the transition of Aboriginal life from stations to the La Grange mission to the era of native title. The power of these heads lies in their multivalent symbolism, as they sit at the crossroads of the artistic, ceremonial and political histories of the Karajarri and the Bidyadanga community.

\section{Acknowledgements}

This essay was made possible by Sam Bayley and the Karajarri Rangers. I am indebted to them for hosting my trip to Bidyadanga, and to my interviewees Anna Dwyer, Mervyn Mulardy Jnr and especially to Aunty Rosie Munroe. Thanks also to people who gave advice and help along the way, including Anne Brody, Chad Creighton, Geoffrey Bagshaw, Uncle Joe Edgar, John Mateer, John Stanton, Katie Glaskin, Naomi Mossenson, Philippa Jahn, Nell Reidy and Tran Tran from the Australian Institute of Aboriginal and Torres Strait Islander Studies, Sarah Ridhuan and Vanessa Russ from the Berndt Museum, and the anonymous reviewers of this paper. Travel to Bidyadanga was enabled by the Australian Research Council through the 'Art of Station Time: Australian Art and Pastoralism’ Discovery Project DP1800103308. 


\section{References}

\section{Archival sources}

\section{Berndt Museum, University of Western Australia}

Dodo, Big John. Interview with John Stanton, 1985. VHS tape.

Petri, Helmut. Correspondence from Helmut Petri to John Stanton dated 8 October 1985.

\section{State Library of Western Australia}

BA368/9, Helmut Petri, 'Fieldtrip to LaGrange', 1960. Photographic album.

\section{Unpublished sources}

Thom, David. 'Kimberley: Out on the Ridges', 2018. Manuscript. Private collection.

\section{Published sources}

Akerman, Kim. 'The Renasence of Aboriginal Law in the Kimberleys'. In Aborigines of the West: Their Past and Their Present, edited by Ronald M. Berndt and Catherine H. Berndt, 234-42. Perth: University of Western Australia Press, 1980.

Ackerman, Kim. 'Stone'. In Paper Stone Tin. Exhibition catalogue. Adelaide: Tandanya, 1990.

Akerman, Kim. 'Big John Dodo'. In Aboriginal and Torres Strait Islander Art: Collection Highlights, edited by Franchesca Cubillo and Wally Caruana. Canberra: National Gallery of Australia, 2010. Accessed 4 September 2019. artsearch.nga.gov.au/detail.cfm?irn=65349.

Allbrook, Malcolm. 'George Coolbul: Imagining a Colonised Life'. Aboriginal History 32 (2008): 49-62. doi.org/10.22459/AH.32.2011.03.

Anonymous. 'Big John Dodo'. In Kimberley Sculpture: A Selection of Carvings by Aboriginal Artists of North Western Australia from the Collection of Australian City Properties Limited, edited by Mary Macha, n.p. Exhibition catalogue, touring exhibition. Perth: Australian City Properties, 1989.

Bunbury, Bill. It's Not the Money It's the Land: Aboriginal Stockmen and the Equal Wages Case. Perth: Fremantle Arts Centre Press, 2002.

Edgar, Joe. 'Indigenous Land Use Agreement - Building Relationships between Karajarri Traditional Owners, the Bidyadanga Aboriginal Community La Grange Inc. and the Government of Western Australia'. Australian Aboriginal Studies 2 (2011): 50-63.

Foster, Robert. 'Rations, Coexistence, and the Colonisation of Aboriginal Labour in the South Australian Pastoral Industry, 1860-1911'. Aboriginal History 24 (2000): 1-26. doi.org/10.22459/AH.24.2011.01.

Grosskopf, Arne. Australian Stockwhips and Other Curios. Melbourne: self-published, 2008. 
Harris, Jonathan. The New Art History: A Critical Introduction. London: Routledge, 2001. doi.org/10.4324/9780203466780.

Hawke, Steve. A Town Is Born: The Fitzroy Crossing Story. Broome, WA: Magabala Books, 2013.

Hokari, Minoru. Gurindji Journey: A Japanese Historian in the Outback. Sydney: UNSW Press, 2011.

Jorgensen, Darren. 'The Art of Station Time: The Aboriginal Experience of Pastoralism in Australia'. World Art7, no. 1 (2017): 107-22. doi.org/10.1080/21500894.2016.1256346.

Mateer, John. 'Invisible Genres, Or On the Virtual and the Actual'. In Invisible Genres: Two Essays on Iconoclasm, edited by John Mateer and Arvi Wattel, 7-59. Perth: John Curtin Gallery, 2017.

McKelson, Kevin. 'DODO'. In The Oxford Companion to Aboriginal Art and Culture, edited by Sylvia Kleinert and Margo Neale, 575-76. Melbourne: Oxford University Press, 2000.

McKelson, Kevin. 'Nadya Nadya Country'. In Aborigines of the West: Their Past and Their Present, edited by Ronald M. Berndt and Catherine H. Berndt, 214-23. Perth: University of Western Australia Press, 1980.

Morphy, Howard. Ancestral Connections: Art and an Aboriginal System of Knowledge. Chicago: University of Chicago Press, 1991.

Morphy, Howard. 'Art Theory and Art Discourse across Cultures: The Yolgnu and Kunwinjku Compared'. In Between Indigenous Australia and Europe: John Mawurndjul, edited by Claus Volkenandt and Christian Kaufmann, 75-102. Canberra and Berlin: Aboriginal Studies Press and Reimer, 2009.

Morphy, Howard. 'Moving the Body Painting into the Art Gallery - Knowing About and Appreciating Works of Aboriginal Art'. Journal of Art Historiography 4 (June 2011): 1-20. Accessed 20 October 2018. arthistoriography.files.wordpress.com/2011/05/moving-thebody-images-_formatted_01dec1.pdf.

Mulardy, Mervyn, Wynston Shoveller and Bhiamie Williamson. 'Karajarri Country: An Interview with Mervyn Mulardy and Wynston Shoveller'. Native Title Newsletter 2 (August 2017): 16-17.

Petri, Helmut and Gisela Petri-Odermann. 'Stability and Change: Present-Day Historic Aspects among Australian Aborigines'. In Australian Aboriginal Anthropology: Modern Studies in the Social Anthropology of the Australian Aborigines, edited by Ronald M. Berndt, 248-76. Perth: University of Western Australia Press, 1970.

Rohr, Emily. 'Bidyandanga'. In Beyond Sacred: Australian Aboriginal Art, The Laverty Collection. Auction catalogue. Deutscher and Hackett, Sydney, 8 March 2015. Accessed 3 July 2019. www.deutscherandhackett.com/38-essay/bidyadanga-emily-rohr.

Shaw, Bruce. Countrymen: The Life Histories of Four Aboriginal Men as Told to Bruce Shaw. Canberra: Australian Institute of Aboriginal Studies, 1986.

Yu, Peter and Sarah Yu. 'Living Water: Kurnagkul'. Habitat Australia 27, no. 3 (1999): 24-26. 
This text is taken from Aboriginal History, Volume 43, 2019, edited by Ingereth Macfarlane, published 2020 by ANU Press, The Australian National University, Canberra, Australia.

doi.org/10.22459/AH.43.2019.04 